\title{
Electronic Cigarette Use Among Working Adults — United States, 2014
}

\author{
Girija Syamlal, MBBS ${ }^{1}$; Ahmed Jamal, MBBS${ }^{2}$; Brian A. King, $\mathrm{PhD}^{2}$; Jacek M. Mazurek, MD ${ }^{1}$
}

Electronic cigarettes (e-cigarettes) are battery-powered devices that deliver a heated aerosol, which typically contains nicotine, flavorings, and other additives, to the user. The e-cigarette marketplace is rapidly evolving, but the long-term health effects of these products are not known. Carcinogens and toxins such as diacetyl, acetaldehyde, and other harmful chemicals have been documented in the aerosol from some e-cigarettes (1-3). On May 5, 2016, the Food and Drug Administration (FDA) finalized a rule extending its authority to all tobacco products, including e-cigarettes.* The prevalence of e-cigarette use among U.S. adults has increased in recent years, particularly among current and former conventional cigarette smokers (4); in 2014, 3.7\% of all U.S. adults, including $15.9 \%$ of current cigarette smokers, and $22.0 \%$ of former cigarette smokers, used e-cigarettes every day or some days (5). The extent of current e-cigarette use among U.S. working adults has not been assessed. Therefore, CDC analyzed 2014 National Health Interview Survey (NHIS) data for adults aged $\geq 18$ years who were working during the week before the interview, to provide national estimates of current e-cigarette use among U.S. working adults by industry and occupation. Among the estimated 146 million working adults, 3.8\% (5.5 million) were current (every day or some days) e-cigarette users; the highest prevalences were among males, non-Hispanic whites, persons aged 18-24 years, persons with annual household income $<\$ 35,000$, persons with no health insurance, cigarette smokers, other combustible tobacco users, and smokeless tobacco users. By industry and occupation, workers in the accommodation and food services industry and in the food preparation and serving-related occupations had the highest prevalence of current e-cigarette use. Higher prevalences of e-cigarette use among specific groups and the

\footnotetext{
*https://federalregister.gov/articles/2016/05/10/2016-10685/deeming-tobaccoproducts-to-be-subject-to-the-federal-food-drug-and-cosmetic-act-as-amendedby-the.
}

effect of e-cigarette use on patterns of conventional tobacco use underscore the importance of continued surveillance of e-cigarette use among U.S. working adults to inform public health policy, planning, and practice.

NHIS data are collected annually from a nationally representative sample of the noninstitutionalized U.S. civilian population through a personal household interview. The NHIS adult core questionnaire is administered to a randomly selected adult aged $\geq 18$ years in each sampled household. In 2014, the NHIS adult sample included 36,697 respondents and the response rate was $58.9 \%(6)$. The NHIS collected information on e-cigarette use for the first time in 2014.

Survey participants were considered to be currently working if they reported "working at a job or business," "with a job or business but not at work," or "working, but not for pay, at a family-owned job or business" during the week before the interview. Information on participants' industry of

\section{INSIDE \\ 562 Elimination of Mother-to-Child Transmission of HIV - Thailand \\ 567 Influenza Activity - United States, 2015-16 Season and Composition of the 2016-17 Influenza Vaccine \\ 576 Vital Signs: Deficiencies in Environmental Control Identified in Outbreaks of Legionnaires' Disease - North America, 2000-2014 \\ 585 Notes from the Field: Intoxication and Deaths Associated with Ingestion of a Racing Fuel and Carbonated Soft Drink Mixture - Tennessee, January 2016 \\ 588 QuickStats}

Continuing Education examination available at http://www.cdc.gov/mmwr/cme/conted_info.html\#weekly.

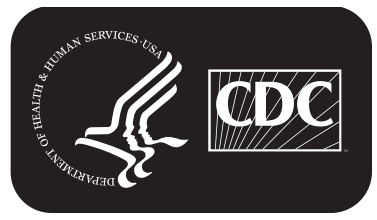

U.S. Department of Health and Human Services Centers for Disease Control and Prevention 
employment and occupation was classified by the National Center for Health Statistics using a standardized coding system (G). Current e-cigarette users were adults who answered "yes" to the question about having ever used an e-cigarette, even one time in the past, and who then reported that they currently used e-cigarettes every day or some days at the time of the survey (5). Current e-cigarette use was also assessed within subgroups defined by current cigarette smoking, use of other combustible tobacco products (cigars/little cigars/ cigarillos, bidis, pipes, or water pipes/hookahs), and current use of smokeless tobacco products (chewing tobacco/snuff/dip, snus, or dissolvable tobacco). Current cigarette smokers were respondents who reported smoking $\geq 100$ cigarettes during their lifetime, and who reported smoking every day or some days at the time of the survey. Former smokers were respondents who reported smoking $\geq 100$ cigarettes during their lifetime, and reported not smoking at the time of the survey. Never smokers were respondents who reported not having smoked 100 cigarettes during their lifetime. Current other combustible tobacco smokers were respondents who reported ever smoking other tobacco products (including cigars/little cigars/cigarillos, bidis, pipes, or water pipes/hookahs), even one time, and who reported smoking other tobacco products every day, some days, or rarely at the time of the survey. Current smokeless tobacco users were respondents who reported ever using smokeless tobacco products that are placed in the mouth or nose (including chewing tobacco, snuff, dip, snus, or dissolvable tobacco, snuff or chewed tobacco), even one time, and who reported use every day, some days, or rarely at the time of the survey.

Data were adjusted for nonresponse and weighted to provide nationally representative estimates. Prevalence estimates and corresponding $95 \%$ confidence intervals were calculated. E-cigarette use was assessed overall, and by age, sex, race/ethnicity, education, annual household income, health insurance status, U.S. census region, perceived health status, current cigarette smoking, other combustible tobacco use, and smokeless tobacco use. Estimates with a relative standard error $>30 \%$ are not reported. Two-sided t-tests ${ }^{\dagger}$ were used to determine statistically significant $(\mathrm{p}<0.05)$ differences between point estimates.

In 2014, an estimated 146 million U.S. adults were working during the week before the NHIS interview. Among working adults, 3.8\% (an estimated 5.5 million) were current e-cigarette users. The prevalences of current e-cigarette use were significantly $(\mathrm{p}<0.05)$ higher among males $(4.5 \%)$ and non-Hispanic whites $(4.5 \%)$, and among persons aged $18-24$ years $(5.1 \%)$, with annual family income $<\$ 35,000(5.1 \%)$, with no health insurance (5.9\%), residing in the Midwest region (4.5\%), and with fair or poor health $(5.7 \%)$ than among females $(3.0 \%)$ and non-Hispanic blacks (1.9\%), and persons aged 45-64 years $(2.9 \%)$, with income $>\$ 75,000(2.6 \%)$, with health insurance (3.4\%), residing in the Northeast region $(2.0 \%)$, and with excellent health (2.4\%) (Table 1). E-cigarette use was also

${ }^{\dagger}$ http://www.cdc.gov/nchs/data/series/sr_10/sr10_256.pdf (page 142).

The MMWR series of publications is published by the Center for Surveillance, Epidemiology, and Laboratory Services, Centers for Disease Control and Prevention (CDC), U.S. Department of Health and Human Services, Atlanta, GA 30329-4027.

Suggested citation: [Author names; first three, then et al., if more than six.] [Report title]. MMWR Morb Mortal Wkly Rep 2016;65:[inclusive page numbers].

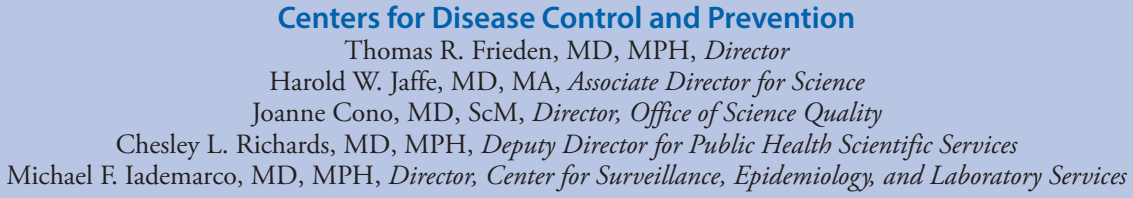

MMWR Editorial and Production Staff (Weekly)

Sonja A. Rasmussen, MD, MS, Editor-in-Chief

Charlotte K. Kent, PhD, MPH, Executive Editor Jacqueline Gindler, MD, Editor

Teresa F. Rutledge, Managing Editor

Douglas W. Weatherwax, Lead Technical Writer-Editor

Soumya Dunworth, PhD, Teresa M. Hood, MS, Technical Writer-Editors

Timothy F. Jones, MD, Chairman

Matthew L. Boulton, MD, MPH

Virginia A. Caine, MD

Katherine Lyon Daniel, PhD

Jonathan E. Fielding, MD, MPH, MBA

David W. Fleming, MD

Martha F. Boyd, Lead Visual Information Specialist

Maureen A. Leahy, Julia C. Martinroe,

Stephen R. Spriggs, Moua Yang, Tong Yang, Visual Information Specialists

Quang M. Doan, MBA, Phyllis H. King, Terraye M. Starr, Information Technology Specialists

MMWR Editorial Board

William E. Halperin, MD, DrPH, MPH

King K. Holmes, MD, PhD

Robin Ikeda, MD, MPH

Rima F. Khabbaz, MD

Phyllis Meadows, PhD, MSN, RN

Jewel Mullen, MD, MPH, MPA
Jeff Niederdeppe, $\mathrm{PhD}$

Patricia Quinlisk, MD, MPH

Patrick L. Remington, MD, MPH

Carlos Roig, MS, MA

William L. Roper, MD, MPH

William Schaffner, MD 
TABLE 1. Current e-cigarette* use prevalence among currently working $^{\dagger}$ adults aged $\geq 18$ years, by selected characteristics National Health Interview Survey, United States, 2014

\begin{tabular}{|c|c|c|c|}
\hline \multirow[b]{2}{*}{ Characteristic } & \multirow{2}{*}{$\begin{array}{l}\text { Estimated } \\
\text { population } \\
(\times 1,000)\end{array}$} & \multicolumn{2}{|c|}{ Estimated e-cigarette use ${ }^{* *}$} \\
\hline & & $\begin{array}{c}\text { No.q } \\
(\times 1,000)\end{array}$ & $\%(95 \% \mathrm{Cl})$ \\
\hline Total & 146,324 & 5,498 & $3.8(3.2-4.3)$ \\
\hline \multicolumn{4}{|l|}{ Age group (yrs) } \\
\hline $18-24$ & 18,401 & 940 & $5.1(3.7-6.6)$ \\
\hline $25-44$ & 63,593 & 2,879 & $4.5(3.9-5.2)$ \\
\hline $45-64$ & 56,641 & 1,620 & $2.9(2.1-3.7)$ \\
\hline$\geq 65$ & 7,689 & 60 & $0.8(0.3-1.2)$ \\
\hline \multicolumn{4}{|l|}{ Sex } \\
\hline Female & 68,478 & 2,046 & $3.0(2.5-3.5)$ \\
\hline \multicolumn{4}{|l|}{ Race/Ethnicity } \\
\hline Hispanic & 23,477 & 584 & $2.5(1.7-3.3)$ \\
\hline White, non-Hispanic & 96,846 & 4,314 & $4.5(3.7-5.2)$ \\
\hline Black, non-Hispanic & 16,629 & 321 & $1.9(1.4-2.5)$ \\
\hline Other & 9,372 & 279 & $3.0(1.7-4.3)$ \\
\hline \multicolumn{4}{|l|}{ Education } \\
\hline$\leq$ High school, GED & 13,439 & 490 & $3.7(2.5-4.8)$ \\
\hline >High school & 132,253 & 5,003 & $3.8(3.2-4.4)$ \\
\hline Unknown & 632 & - ${ }^{\dagger+}$ & $-(-)$ \\
\hline \multicolumn{4}{|l|}{ Family income (\$) } \\
\hline $0-34,999$ & 29,754 & 1,515 & $5.1(4.4-5.9)$ \\
\hline $35,000-74,999$ & 42,368 & 1,962 & $4.6(3.8-5.5)$ \\
\hline$\geq 75,000$ & 62,205 & 1,716 & $2.8(1.7-3.8)$ \\
\hline Unknown & 11,997 & 305 & $2.6(1.3-3.9)$ \\
\hline \multicolumn{4}{|l|}{ Health insurance } \\
\hline Insured & 125,316 & 1,186 & $3.4(2.9-3.9)$ \\
\hline Not insured & 20,170 & 4,236 & $5.9(4.6-7.3)$ \\
\hline Unknown & 838 & - & $-(-)$ \\
\hline \multicolumn{4}{|l|}{ U.S. census region $\S^{\S}$} \\
\hline Northeast & 24,940 & 491 & $2.0(1.2-2.7)$ \\
\hline Midwest & 34,988 & 1,567 & $4.5(3.3-5.7)$ \\
\hline South & 53,018 & 2,119 & $4.0(2.9-5.1)$ \\
\hline West & 33,377 & 1,321 & $4.0(3.1-4.8)$ \\
\hline \multicolumn{4}{|l|}{ Perceived health } \\
\hline Excellent & 50,419 & 1,197 & $2.4(1.9-2.9)$ \\
\hline Good & 87,781 & 3,847 & $4.4(3.7-5.1)$ \\
\hline Fair/Poor & 8,096 & 454 & $5.7(3.1-8.3)$ \\
\hline Unknown & 28 & - & $-(-)$ \\
\hline
\end{tabular}

Abbreviations: $\mathrm{Cl}=$ confidence interval; $\mathrm{GED}=$ General Educational Development certificate or diploma.

* Current users were adults who used e-cigarettes at least once in their lifetime and currently use every day or some days.

† Adults who reported "working at a job or business"; "with a job or business but not at work"; or "working, but not for pay, at a family-owned job or business" during the week before the interview.

$\S$ Weighted to provide national estimates.

I Estimated number of e-cigarette users among working adults.

** E-cigarette use was significantly associated $(p<0.05)$ with age, gender, race, income, health insurance coverage, perceived health status, and region.

${ }^{\dagger}$ Estimates suppressed because relative standard error for the estimate was $>30 \%$.

$\S \S$ http://www.census.gov/econ/census/help/geography/regions_and_ divisions.html.

ๆศ Perceived self-reported health categorized on the basis of the response to the question, "Would you say your health in general is excellent, good, fair, or poor?" significantly $(\mathrm{p}<0.05)$ higher among current cigarette smokers $(16.2 \%)$ and users of other combustible tobacco products $(15.0 \%)$ or smokeless tobacco $(9.7 \%)$ than among former $(4.3 \%)$ and never $(0.5 \%)$ cigarette smokers, and nonusers of combustible tobacco $(2.9 \%)$ or smokeless tobacco $(3.6 \%)$ (Table 2).

By industry, reported e-cigarette use was highest among workers in accommodation and food services (6.9\%) and lowest among workers in education services (1.8\%). By occupation, prevalences of e-cigarette use were highest among workers in food preparation and serving-related occupations $(6.8 \%)$ and lowest among workers in business and financial operations occupations (2.3\%) (Table 3 ).

TABLE 2. Estimated prevalence of current e-cigarette* use, by current cigarette smoking status, ${ }^{\dagger}$ current other combustible ${ }^{\S}$ tobacco use status, and current smokeless ${ }^{\natural}$ tobacco use status among working ${ }^{* *}$ adults aged $\geq 18$ years - National Health Interview Survey, United States, 2014

\begin{tabular}{|c|c|c|c|}
\hline \multirow[b]{2}{*}{ Tobacco use } & \multirow{2}{*}{$\begin{array}{l}\text { Estimated } \\
\text { working } \\
\text { population } \\
(x+ \\
(x 1,000)\end{array}$} & \multicolumn{2}{|c|}{$\begin{array}{l}\text { Estimated current } \\
\text { e-cigarette use }\end{array}$} \\
\hline & & $\begin{array}{c}\text { No. }{ }^{\S} \\
(\times 1,000)\end{array}$ & $\%(95 \% \mathrm{Cl})$ \\
\hline \multicolumn{4}{|c|}{ Cigarette smoking status } \\
\hline Current & 23,739 & 3,827 & $16.2(13.9-18.5)$ \\
\hline Former & 27,854 & 1,198 & $4.3(3.2-5.4)$ \\
\hline Never & 93,936 & 473 & $0.5(0.3-0.7)$ \\
\hline Unknown & 795 & —าศ & $-(-)$ \\
\hline \multicolumn{4}{|c|}{ Other combustible tobacco use $\mathrm{e}^{\S}$} \\
\hline Yes & 10,519 & 1,578 & $15.0(11.0-19.1)$ \\
\hline No & 135,103 & 3,920 & $2.9(2.5-3.3)$ \\
\hline Unknown & 702 & - & $-(-)$ \\
\hline \multicolumn{4}{|c|}{ Smokeless tobacco use $\mathrm{f}^{\text {? }}$} \\
\hline Yes & 5,139 & 499 & $9.7(6.5-12.9)$ \\
\hline No & 140,428 & 4,999 & $3.6(3.0-4.1)$ \\
\hline Unknown & 757 & - & $-(-)$ \\
\hline
\end{tabular}

Abbreviation: $\mathrm{Cl}=$ confidence interval.

* Current users are adults who used e-cigarettes at least once in their lifetime and currently use every day or some days.

${ }^{\dagger}$ Current cigarette smokers smoked $\geq 100$ cigarettes during their lifetime and currently smoke every day or somedays. Former cigarette smokers smoked $\geq 100$ cigarettes during their lifetime and currently do not smoke. Never smokers are adults who reported not smoking 100 cigarettes in their lifetime.

$\S$ Used other non-cigarette combustible tobacco products (cigars/little cigars/ cigarillos; bidis, pipes, or water pipes/hookahs) at least one time in the past, and currently smoke every day, some days, or rarely.

" Used smokeless tobacco products (chewing tobacco/snuff/dip, snus, or dissolvable tobacco) at least one time in the past, and currently use them every day, some days, or rarely.

** Adults who reported "working at a job or business"; "with a job or business but not at work"; or "working, but not for pay, at a family-owned job or business" during the week before the interview.

t+ Weighted to provide national estimates for working adults.

$\S \S$ Estimated number of e-cigarette users among working adults.

กๆ Estimates suppressed because relative standard error for the estimate was $>30 \%$. 
Table 3. Current e-cigarette use* prevalence among currently working $^{\dagger}$ adults aged $\geq 18$ years, by industry and occupation group — National Health Interview Survey, 2014

\begin{tabular}{|c|c|c|c|}
\hline \multirow[b]{2}{*}{ Industry/Occupation } & \multirow{2}{*}{$\begin{array}{l}\text { Estimated } \\
\text { population } \\
(\times 1,000) \\
\end{array}$} & \multicolumn{2}{|c|}{$\begin{array}{l}\text { Estimated current } \\
\text { e-cigarette use }\end{array}$} \\
\hline & & $\begin{array}{l}\text { No. } \\
(\times 1,000)^{\text {ศ }}\end{array}$ & $\%(95 \% \mathrm{Cl})$ \\
\hline \multicolumn{4}{|l|}{ Industries } \\
\hline Accommodation and food services & 10,183 & 700 & $6.9(4.9-8.9)$ \\
\hline Wholesale trade & 3,569 & 184 & $5.2(2.6-7.8)$ \\
\hline Manufacturing & 14,981 & 718 & $4.8(2.1-7.5)$ \\
\hline $\begin{array}{l}\text { Administrative and support and } \\
\text { waste management and } \\
\text { remediation services }\end{array}$ & 6,341 & 297 & $4.7(2.8-6.5)$ \\
\hline Retail trade & 14,764 & 683 & $4.6(3.4-5.9)$ \\
\hline Construction & 8,955 & 406 & $4.6(2.9-6.2)$ \\
\hline $\begin{array}{l}\text { Other services (except public } \\
\text { administration) }\end{array}$ & 7,308 & 285 & $3.9(2.1-5.7)$ \\
\hline Arts, entertainment, and recreation & 3,172 & 96 & $3.0(1.4-4.6)$ \\
\hline $\begin{array}{l}\text { Professional, scientific, and } \\
\text { technical services }\end{array}$ & 10,720 & 307 & $2.9(1.9-3.9)$ \\
\hline Health care and social assistance & 19,293 & 521 & $2.7(1.8-3.6)$ \\
\hline Public administration & 6,849 & 172 & $2.5(1.2-3.8)$ \\
\hline Finance and insurance & 6,701 & 153 & $2.3(1.2-3.4)$ \\
\hline Education services & 13,893 & 249 & $1.8(1.0-2.6)$ \\
\hline All others ${ }^{\dagger \dagger}$ & 16,748 & 637 & $3.3(2.4-5.3)$ \\
\hline Refused, not ascertained, don't know & 2,847 & - ${ }^{* *}$ & $-(-)$ \\
\hline \multicolumn{4}{|l|}{ Occupations } \\
\hline $\begin{array}{l}\text { Food preparation and } \\
\text { serving related }\end{array}$ & 7,863 & 534 & $6.8(4.6-9.0)$ \\
\hline Production & 8,044 & 422 & $5.3(3.7-6.9)$ \\
\hline Office and administrative support & 17,389 & 846 & $4.9(3.3-6.4)$ \\
\hline $\begin{array}{l}\text { Building and grounds cleaning } \\
\text { and maintenance }\end{array}$ & 5,811 & 251 & $4.3(2.4-6.3)$ \\
\hline $\begin{array}{l}\text { Transportation and material } \\
\text { moving }\end{array}$ & 8,192 & 341 & $4.2(2.4-6.0)$ \\
\hline Sales and related & 14,467 & 580 & $4.0(2.8-5.2)$ \\
\hline Personal care and service & 5,654 & 221 & $3.9(2.1-5.7)$ \\
\hline Construction and extraction & 7,240 & 253 & $3.5(2.1-4.9)$ \\
\hline Healthcare support & 3,046 & 92 & $3.0(1.3-4.8)$ \\
\hline Management & 14,114 & 368 & $2.6(1.7-3.6)$ \\
\hline $\begin{array}{l}\text { Healthcare practitioners } \\
\text { and technical }\end{array}$ & 8,482 & 206 & $2.4(1.5-3.4)$ \\
\hline Business and financial operations & 7,230 & 164 & $2.3(1.1-3.4)$ \\
\hline $\begin{array}{l}\text { Architecture and engineering, and } \\
\text { computer and mathematical }\end{array}$ & 8,009 & 148 & $1.9(0.9-2.9)$ \\
\hline All others $\S \S$ & 27,990 & 1,005 & $3.6(2.1-5.1)$ \\
\hline $\begin{array}{l}\text { Refused, not ascertained, } \\
\text { don't know }\end{array}$ & 2,793 & - & $-(-)$ \\
\hline
\end{tabular}

Abbreviation: $\mathrm{Cl}=$ confidence interval.

* Current users are adults who used e-cigarettes at least once in their lifetime and currently use every day or some days.

† Adults who reported "working at a job or business"; "with a job or business but not at work"; or "working, but not for pay, at a family-owned job or business" during the week before the interview.

$\S$ Weighted to provide national estimates using the survey sample weights for each participant.

" Estimated number of e-cigarette users among working adults.

** Estimates suppressed because relative standard error for the estimate was $>30 \%$.

${ }^{+\dagger}$ Includes all industries with unreliable (relative standard error $>30 \%$ ) estimates combined: mining; transportation and warehousing; utilities; information; real estate, rental, and leasing; agriculture, forestry, fishing and hunting; management of companies and enterprises; and armed forces.

$\S \S$ Includes all occupations with unreliable (relative standard error $>30 \%$ ) estimates combined: installation and maintenance and repair; protective services; farming, fishing and forestry, community and social services; arts design, entertainment sports and media; legal, life, physical and social science; education, training, and library; and military occupations.

\section{Discussion}

In 2014, an estimated $3.8 \%$ of U.S. working adults were current e-cigarette users. Similar to findings previously reported among the overall U.S. adult population (7), higher prevalences of current e-cigarette use were observed among workers aged 18-24 years, males, adults with annual household income $<\$ 35,000$, adults with no health insurance, current and former cigarette smokers, and current users of other combustible tobacco products and smokeless tobacco. Current use of e-cigarettes varied by industry and occupation. Consistent with previous research reports indicating higher conventional cigarette smoking prevalences among workers in the accommodation and food services industry (8), prevalences of e-cigarette use were highest among workers in accommodation and food services industry and among workers in food preparation and serving-related occupations. These findings underscore the importance of evidence-based interventions, in coordination with continued surveillance of e-cigarette use among U.S. workers, particularly with regard to concurrent use of e-cigarettes with other tobacco products, to reduce tobaccorelated disease and death among this population.

E-cigarettes have been promoted to aid in smoking cessation (9); however, the U.S. Preventive Services Task Force has concluded that current evidence is insufficient to recommend e-cigarettes for tobacco cessation among adults, $\$$ and e-cigarettes are not an FDA-approved cessation aid.9 E-cigarettes also have been marketed as an alternative to smoking in locations where conventional cigarette smoking is prohibited (9). Data on the potential health impact of e-cigarette aerosol exposure on users and bystanders are limited (10); however, harmful and potentially harmful chemicals have been documented in some e-cigarette cartridges and in the aerosol emitted by these products (1-3). Despite uncertainty over the long-term health effects of e-cigarette use, rapid increases have occurred in the awareness, experimentation, and use of these products among U.S. adults (3). In May 2016, FDA finalized a rule extending the agency's authority to all tobacco products, including e-cigarettes.

The findings in this report are subject to at least four limitations. First, small sample size limited the precision of estimates for some subpopulations. Second, the NHIS response rate of $58.9 \%$ might have resulted in nonresponse bias, even after adjustment for nonresponse. Third, the employment information applied only to jobs held the week before the interview; those jobs might not have been representative of the long-term

\footnotetext{
\$http://www.uspreventiveservicestaskforce.org/Page/Document/ RecommendationStatementFinal/tobacco-use-in-adults-and-pregnant-womencounseling-and-interventions1.

' http://www.cdc.gov/niosh/docs/2015-113/pdfs/fy15_cib-67_2015-113_v3.pdf.
} 


\section{Summary}

What is already known about this topic?

The prevalence of e-cigarettes use among U.S. adults has increased in recent years, particularly among current and former cigarettes smokers. In 2014, an estimated $3.7 \%$ of U.S. adults, including $15.9 \%$ of current cigarette smokers and $22.0 \%$ of former cigarette smokers, currently used e-cigarettes every day or some days.

What is added by this report?

In 2014, an estimated 5.5 million (3.8\%) of 146 million U.S. working adults were current e-cigarette users. An estimated $16.2 \%$ of current cigarette smokers, $15.0 \%$ of other combustible tobacco users, and $9.7 \%$ of smokeless tobacco users currently used e-cigarettes. The highest e-cigarette use prevalence was among workers in accommodation and food services (6.9\%) industry, and among workers in food preparation and serving related occupations (6.8\%).

What are the implications for public health practice?

Higher prevalences of e-cigarette use among certain groups, coupled with uncertainties regarding the safety of e-cigarette use and the effect of e-cigarette use on patterns of conventional tobacco use, underscore the importance of continued public health surveillance of e-cigarette use among U.S. working adults. Employers, businesses, trade associations, and worker representatives can work in partnership with their state and local health departments to educate workers about the health risks of tobacco use and the benefits of quitting tobacco use completely.

work history of the respondents. Finally, although validity of self-reported smoking status has been confirmed, the accuracy of self-reported e-cigarette use is uncertain.

Recent increases in e-cigarette use among U.S. adults, coupled with uncertainties regarding the safety of e-cigarette use and the effect of e-cigarette use on patterns of conventional tobacco use, underscore the importance of continued public health surveillance of e-cigarette use. Implementation of proven strategies to reduce tobacco use and promote tobacco-free norms in the workplace is also warranted, particularly among populations with the greatest prevalence of use. For example, employers can implement policies prohibiting the use of all forms of tobacco use in the workplace. ${ }^{* *}$ Employers can also offer comprehensive tobacco cessation services within their employee health care plans and wellness programs, including coverage of FDA-approved cessation medications $(8,10)$. Furthermore, employers, businesses, trade associations, and worker representatives can work in partnership with their state and local health departments, to educate workers about the health risks of tobacco use and the benefits of quitting tobacco use completely.

\footnotetext{
** http://www.acoem.org/uploadedFiles/Public_Affairs/Policies_And_Position_ Statements/Guidelines/Guidelines/Guidance_to_Employers_on_Integrating.pdf.
}

\section{Acknowledgments}

Douglas O. Johns, Respiratory Health Division, National Institute for Occupational Safety and Health, CDC; Israel T. Agaku, Office on Smoking and Health, National Center for Chronic Disease Prevention and Health Promotion, CDC.

${ }^{1}$ Respiratory Health Division, National Institute for Occupational Safety and Health, CDC; ${ }^{2}$ Office on Smoking and Health, National Center for Chronic Disease Prevention and Health Promotion, CDC.

Corresponding author: Girija Syamlal, GSyamlal@cdc.gov, 304-285-5827.

\section{References}

1. Allen JG, Flanigan SS, LeBlanc M, et al. Flavoring chemicals in e-cigarettes: diacetyl, 2,3-pentanedione, and acetoin in a sample of 51 products, including fruit-, candy-, and cocktail-flavored e-cigarettes. Environ Health Perspect 2016;124:733-9. http://dx.doi.org/10.1289/EHP348

2. Callahan-Lyon P. Electronic cigarettes: human health effects. Tob Control 2014;23(Suppl 2):ii36-40. http://dx.doi.org/10.1136/ tobaccocontrol-2013-051470

3. Cobb CO, Weaver MF, Eissenberg T. Evaluating the acute effects of oral, non-combustible potential reduced exposure products marketed to smokers. Tob Control 2010;19:367-73. http://dx.doi.org/10.1136/ tc. 2008.028993

4. King BA, Patel R, Nguyen KH, Dube SR. Trends in awareness and use of electronic cigarettes among US adults, 2010-2013. Nicotine Tob Res 2015;17:219-27. http://dx.doi.org/10.1093/ntr/ntu191

5. Schoenborn CA, Gindi RM. Electronic cigarette use among adults: United States, 2014. NCHS Data Brief no. 217. Hyattsville, MD: US Department of Health and Human Services, CDC; 2015. http://www. cdc.gov/nchs/data/databriefs/db217.pdf

6. CDC. 2014 National Health Interview Survey (NHIS) public use data release: NHIS survey description. Hyattsville, MD: US Department of Health and Human Services, CDC; 2014. ftp://ftp.cdc.gov/pub/ Health_Statistics/NCHS/Dataset_Documentation/NHIS/2014/ srvydesc.pdf

7. Jamal A, Homa DM, O'Connor E, et al. Current cigarette smoking among adults_-United States, 2005-2014. MMWR Morb Mortal Wkly Rep 2015;64:1233-40. http://dx.doi.org/10.15585/mmwr.mm6444a2

8. CDC. Current cigarette smoking prevalence among working adultsUnited States, 2004-2010. MMWR Morb Mortal Wkly Rep 2011;60:1305-9.

9. US Department of Health and Human Services. The health consequences of smoking - 50 years of progress: a report of the Surgeon General. Atlanta, GA: US Department of Health and Human Services, CDC; 2014. http://www.surgeongeneral.gov/library/reports/50-years-ofprogress/full-report.pdf

10. Czogala J, Goniewicz ML, Fidelus B, Zielinska-Danch W, Travers MJ, Sobczak A. Secondhand exposure to vapors from electronic cigarettes. Nicotine Tob Res 2014;16:655-62. http://dx.doi.org/10.1093/ntr/ntt203 